\title{
The Effects of Blends of Enugu Coal and Anthracite on Tin Smelting Using Nigerian Dogo Na Hauwa Cassiterite
}

\author{
Fatai Afolabi Ayeni*, OladunniOyelola Alabi, Rose Okara \\ National Metallurgical Development Centre, Jos, Nigeria \\ Email: ${ }^{*}$ ayeflo@yahoo.com
}

Received September 10, 2013; revised October 18, 2013; accepted October 26, 2013

Copyright (C) 2013 Fatai Afolabi Ayeni et al. This is an open access article distributed under the Creative Commons Attribution License, which permits unrestricted use, distribution, and reproduction in any medium, provided the original work is properly cited.

\begin{abstract}
The effects of blending Enugu coal and anthracite on tin smelting using Nigerian Dogo Na Hauwa cassiterite have been studied. The work utilized various blends ranging from $100 \%$ to $0 \%$ anthracite. The content of the Enugu coal in the blend varied from $5 \%$ to $100 \%$. The various tin metal recovery percentage for each batch of smelting using various blends was noted. Anthracite alone had the highest recovery of $71.90 \%$ followed by $5 \%$ blend of Enugu with anthracite. The result, however, showed that as the Enugu Coal was increased in the blend, the recovery was also decreasing. This equally affected the quality of tin metal recovered by increasing the grade. The work recommended that since the cost of production is the critical issue, 5\% - 15\% range of Enugu Coal should be used in preparing blends to bring down the cost of imported anthracite which is put at $\$ 906.69$ per ton. The use of $15 \%$ Enugu coal will result in lowering the cost of imported anthracite by $\$ 136.0$.
\end{abstract}

Keywords: Effects; Blending; Enugu Coal; Anthracite; Smelting; Cassiterite; Tin

\section{Introduction}

The cost of energy in the extractive industry is in the increase on daily basis in the world today. In Nigeria, for instance, the high cost of electricity, petroleum products and imported anthracite has caused most of the tin smelting companies in the country to close down [1]. This is a very ugly trend and has resulted in the loss of jobs and a falling standard of living in the country. Today a lot of people in Jos, Plateau State of Nigeria, who were working in tin smelting companies, are without job and seriously suffering with their families [1]. The only way out of this problem is a concerted effort towards research. It has become necessary to develop a cost effective approach in tin smelting in Nigeria. Areas in production chain that are responsible for high cost of tin smelting have to be reviewed, and data collected from most of the smelting companies around Jos revealed that a major contributor to the high cost of smelting tin ore is the input anthracite used as the reductant. This raw material is imported at the cost of $\$ 906,667$ per ton [1] and contributes about almost $50 \%$ to the cost of production per ton of tin produced. This high cost of anthracite and the need to increase local content in smelting of cassiterite inform-

*Corresponding author. ed this research.

Nigeria has a large deposit of coal which was only well exploited during the colonial era; much of the period after the exit of the colonial masters has seen the mines idle without any activity [2]. This coal was in past time used for firing of locomotive trains and the orji River thermal power station and other heating activities in homes and factories [2]. Nigerian coals are sub-Bituminous and Bituminous in nature. They are not fully matured. The stages in the formation of coal from vegetable/Plant (wood) matters are as follows:

Plant debris (wood) $\rightarrow$ Peat $\rightarrow$ Lignite $\rightarrow$ Brown coal $\rightarrow$ Sub-bituminous coal $\rightarrow$ Bituminous coal $\rightarrow$ Semi anthracite $\rightarrow$ anthracite coal $\rightarrow$ graphite [3].

Anthracite is a natural occurring coal, and has a good purity [4] which is absent in most Nigerian coals. Some of the Short comings of Nigerian coals include high moisture content, Ash and volatile matters. Other problems are high sulphur content in some deposits and low fixed carbon [1,5].

Blending is a practice which has been in long usage in the extractive industry majorly to bring down cost and to improve the quality of the final mix. Blending is the mixing of two or more types of materials from two or more sources to even out variations in physical and or 
chemical qualities to obtain a more uniform material of desired qualities over an extended period $[4,6]$. This means that different coals from various sources can be blended, just as iron ore blend may be made up of ores from different sources or it may also include materials much as Coke breeze, Flue dust, Lime stone etc. $[4,6]$.

Plateau state and indeed Nigeria have abundant tin ore deposits. As it is well known that tin does not occur naturally in nature as a free element, the main source is a mineral ore called Cassiterite, with a chemical formula $\mathrm{SnO}_{2}$ [7]. Most of the tin ore mined in Nigeria is in Alluvia form. Proven reserve of the mineral in the country is put at 300,000 MT $[1,8]$. The Tin ore is concentrated before smelting to reduce the tin ore to elemental tin using reverberatory furnaces and the operating temperature is usually in the range of $1200^{\circ} \mathrm{C}-1300^{\circ} \mathrm{C}$. The smelted tin is then transferred to the refining unit where it is brought to the commercial specified composition [1,9].

The objective of this work is to determine the effects of using a blended coal made up of anthracite (imported) and Enugu Coal (local) for extracting tin metal from Dogo Na Hauwa cassiterite deposit near Jos, Plateau State, North-Central Nigeria.

The objective of this work is to know the cost, quality and yield economic effects of the blended coal on smelting of cassiterite. The work is particularly tailored to bring down the cost of production of tin smelting plants in Nigeria using coal blends of local coal and high purity imported anthracite.

\section{Materials and Methods}

\subsection{Materials}

The materials used for the work were high grade Cassiterite concentrate assaying 70\% Tin (Sn) (Tin ore deposit located at Dogo Na Hauwa Village and Kudedu mines in Jos East Local Government area of Plateau state, North Central Nigeria), Anthracite (Sourced from Makeri Smelting Company, Jos), Enugu Coal (Sourced from National Metallurgical Development Centre, Jos), Limestone from Jakura mines, engine oil, diesel, and firewood.

\subsection{Equipment}

Some of the equipment used for the research work included: a $20 \mathrm{~kg}$ capacity reverberatory furnace, rambling metal rod, ladle, launder, Siphon, mould, Tapping and Bleeding rod, Tapping Pot, Energy Dispersive X-Ray Florescence (ED-XRF) Spectrometer, Shovel, Pyrometer, and weighing balance.

\section{Methods}

$10 \mathrm{~kg}$ of high concentrate Cassiterite was mixed thor- oughly with $100 \%$ by weight of Anthracite amounting to $800 \mathrm{gms}$ and lime of weight $400 \mathrm{gms}$. These were then charged into already preheated furnace at a high temperature of $1400^{\circ} \mathrm{C}$ for a soaking period of $8 \mathrm{hrs}$. After which rambling or stirring with rambling rod was done frequently, especially during the later stage. The firing continued for $4 \mathrm{hrs}$, till concentrate melt enough to give a pool of molten tin. The unwanted impurities floating on top of the molten tin was tapped using a tapping rod. This was followed by continuous heating of the Furnace for another 2 hours, after which final bleeding of the tin metal in molten form was carried out through the tapping hole of the furnace, and then cast into ingot. After the bleeding, firing of the furnace continued for another 2 hours till the slag became molten enough at a temperature of $1450^{\circ} \mathrm{C}$ for slag tapping. The slag was solidified in water tanks to granules. The furnace was then cleaned for another round of smelting operation.

The tin metal and the slag recovered were weighed and the weights recorded. The next charge of $10 \mathrm{~kg}$ cassiterite, $400 \mathrm{gms}$ of limestone and variation of the $800 \mathrm{gms}$ of reducing agent, being blends of anthracite and Enugu coal in the following proportions $95 / 5,90 / 10,85 / 15$, $80 / 20,75 / 25,50 / 50$, and $0 / 100$ was smelted and the recovery and slag quantity recorded.

The percentage recovery was calculated using the two product formula:

$$
R=C c / F f \times 100
$$

where, $R=$ recovery (\%); $C=$ weight of concentrate $(\mathrm{kg})$; $c=$ concentrate assay $(\%) ; F=$ weight of feed $(\mathrm{kg}) ; f=$ feed assay (\%).

\section{Results and Discussion}

\subsection{Results}

The chemical composition of Nigerian Dogo Na Hauwa Cassiterite concentrate, proximate analysis and calorific value of as-received Anthracite/Coal blends, ultimate analysis-moisture and ash-free basis, and chemical analysis of Jakuralimestone using wet analysis are presented in Tables 1-4 respectively. Figures 1 and 2 were the graphical representation of effect of Enugu Coal in the blend on the recovery and grade of tin metal respectively.

\subsection{Discussion}

The compositional analysis of the input raw materials used during the smelting operation is shown in Tables 1-4. Table 1 shows that Dogo Na Hauwa tin concentrate has a cassiterite content of $85.4 \%$ which has a tin content close to $78.6 \%$ obtained for the purest cassiterite mineral $\left(\mathrm{SnO}_{2}\right)$ [9]. The impurities present were equally minimal. The silica content was $0.02 \%$ the cassiterite is therefore a high grade cassiterite. 
Table 1. Chemical composition of Dogo Na Hauwa cassiterite concentrate.

\begin{tabular}{|c|c|c|c|c|c|c|c|c|c|c|c|c|}
\hline $\begin{array}{l}\text { Channel } \\
\text { Compound } \\
\text { Conc. Unit }\end{array}$ & $\begin{array}{c}\mathrm{Si} \\
\mathrm{SiO}_{2} \\
0.02 \%\end{array}$ & $\begin{array}{c}\mathrm{Ca} \\
\mathrm{CaO} \\
4.28 \%\end{array}$ & $\begin{array}{c}\mathrm{Ti} \\
\mathrm{TiO}_{2} \\
1.89 \%\end{array}$ & $\begin{array}{c}\mathrm{Mn} \\
\mathrm{MnO} \\
0.11 \%\end{array}$ & $\begin{array}{c}\mathrm{Fe} \\
\mathrm{Fe}_{2} \mathrm{O}_{3} \\
3.19 \%\end{array}$ & $\begin{array}{c}\mathrm{Ni} \\
\mathrm{NiO} \\
0.007 \%\end{array}$ & $\begin{array}{c}\mathrm{Se} \\
\mathrm{SeO}_{2} \\
0.007 \%\end{array}$ & $\begin{array}{c}\mathrm{Y} \\
\mathrm{Y}_{2} 0_{3} \\
0.059 \%\end{array}$ & $\begin{array}{c}\mathrm{Zr} \\
\mathrm{ZrO}_{2} \\
0.341 \%\end{array}$ & $\begin{array}{c}\mathrm{Nb} \\
\mathrm{Nb}_{2} \mathrm{O}_{5} \\
2.20 \%\end{array}$ & $\begin{array}{c}\mathrm{Sn} \\
\mathrm{SnO}_{2} \\
85.4 \%\end{array}$ & $\begin{array}{c}\mathrm{Ce} \\
\mathrm{CeO}_{2} \\
0.54 \%\end{array}$ \\
\hline Channel & & $\mathrm{Nd}$ & & $\mathrm{Ta}$ & & W & & $\mathrm{Hg}$ & & $\mathrm{Bi}$ & \multicolumn{2}{|c|}{$\mathrm{Th}$} \\
\hline Compound & & $\mathrm{Nd}_{2} \mathrm{O}_{3}$ & & $\mathrm{Ta}_{2} \mathrm{O}_{3}$ & & $\mathrm{WO}_{3}$ & & $\mathrm{HgO}$ & & $\mathrm{Bi}_{2} \mathrm{O}_{3}$ & \multicolumn{2}{|c|}{$\mathrm{ThO}_{2}$} \\
\hline Conc Unit & & $0.18 \%$ & & $0.917 \%$ & & $0.25 \%$ & & $0.010 \%$ & & $0.007 \%$ & \multicolumn{2}{|c|}{$0.00 \%$} \\
\hline
\end{tabular}

Table 2. Proximate analysis and calorific value of as-received anthracite/coal blends.

\begin{tabular}{cccccc}
\hline Rank & Moisture (\%) & Ash (\%) & Volatile matter (\%) & Fixed Carbon (\%) & Calorific Value. (Calories per gms) $^{2}$ \\
\hline Coal & 20.7 & 3.9 & 30.7 & 44.7 & 5572 \\
Anthracite & 4.2 & 2.4 & 3.1 & 90.3 & 7662 \\
\hline
\end{tabular}

Source: National Metallurgical Development Centre, Jos, Nigeria (2006).

Table 3. Ultimate analysis-moisture and ash-free basis.

\begin{tabular}{cccccc}
\hline Rank & Carbon (\%) & Hydrogen (\%) & Nitrogen (\%) & Sulfur (\%) & Oxygen (\%) \\
\hline Coal & 66.7 & 5.6 & 1.6 & 0.5 & 18.5 \\
Anthracite & 94.9 & 1.8 & 0.7 & 0.8 & 1.8 \\
\hline
\end{tabular}

Source: M.M.M, Dadinkowa, (1999) Jos.

Table 4. Chemical analysis of Jakura limestone as determined using wet analysis.

\begin{tabular}{ccccccccccc}
\hline $\mathrm{S} / \mathrm{N}$ & DEPOSITE & $\mathrm{CaO}$ & $\mathrm{MgO}$ & $\mathrm{SiO}_{2}$ & $\mathrm{TiO}_{2}$ & $\mathrm{Fe}_{2} \mathrm{O}_{3}$ & $\mathrm{Al}_{2} \mathrm{O}_{3}$ & $\mathrm{~K}_{2} \mathrm{O}$ & $\mathrm{Na}_{2} \mathrm{O}$ & L.O.I \\
\hline 1. & Jakura & 55.23 & 0.45 & 0.31 & 0.01 & 0.04 & 0.04 & 0.02 & 0.03 & 43.58 \\
\hline
\end{tabular}

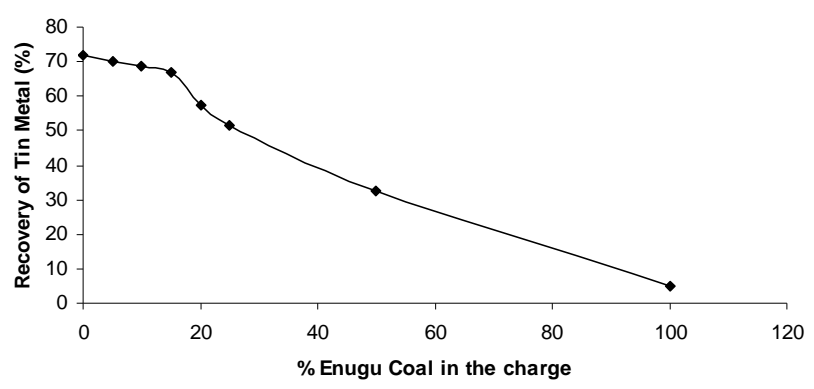

Figure 1. Effect of Enugu coal in the blend on the recovery of tin metal.

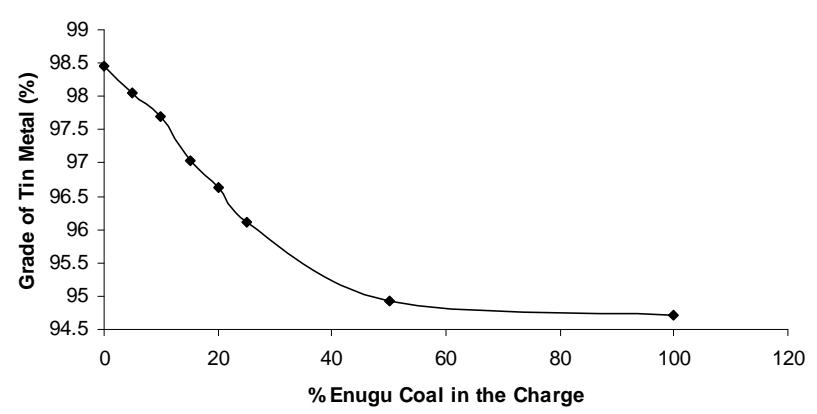

Figure 2. Effect of Enugu coal in the blend on the grade of tin metal.

Tables 2 and 3 show the proximate and ultimate analysis of anthracite, Enugu Coal and Coke. Enugu Coal has the highest moisture content followed by anthracite and coke has the least. This is true when considering the age and geological formation of the two coals. And coke by nature of production is supposed to have the least moisture content. High moisture content is undesirable since it reduces the calorific value of the fuel; this is confirmed by the calorific value of the coals in Table 2 . It also increases the consumption of coal for heating purposes although there may be instances where moisture is deliberately introduced to the coal $[3,10]$. Anthracite has the highest percentage of carbon $(94.96 \%)$ followed by the coke $(82.4 \%)$ and Enugu coal has the least (66.7\%). The high carbon containing coal will have higher calorific value [3,10]. Enugu coal has a higher Ash content of $3.9 \%$, higher ash content in coal are undesirable. In general, because it makes coal harder and stronger and has lower calorific value $[3,10]$, it also produces more slag impurities in the furnace.

Table 4 shows the chemical composition of the Jakura limestone used as fluxing agent. It has a Calcium oxide $(\mathrm{CaO})$ value of $55.23 \%$ and less impurity thereby reducing the likelihood of containing the tin metal produced.

Figure 1 shows the effect of adding Enugu Coal to anthracite on the recovery of thin metal during smelting of Dogo Na Hauwa tin concentrate. The figure shows that as the amount of Enugu Coal increases against the quantity of cassiterite; the recovery of tin metal from the 
concentrate reduces. It therefore means that increasing the amount of Enugu coal in the blend will lead to decrease in the recovery of tin metal. This is a negative effect which can be traced back to the composition of Enugu Coal as discussed earlier. It has low fixed Carbon, high moisture content and ash and high volatile matter and low fix calorific value when compared to the anthracite. However, the essence of the introduction of the Enugu Coal to the anthracite is to bring down the cost of producing tin metal using anthracite only, it will therefore be reasonable to choose a range of the blend where the recovery is not too low and this range is $5 \%-15 \%$ addition of Enugu coal. This will amount to the saving of $\$ 136$ per ton of anthracite used [11].

Figure 2 shows the effect of adding Enugu Coal to anthracite on grade/quality of tin metal extracted. The figure shows that as Enugu coal is increased in the blend the grade of tin metal is decreased. This is indicated by the falling of the curve from left to right. It can therefore be said that as the quantity of Enugu coal is increased against anthracite, there is a negative effect on the grade and quality of tin metal recovered. This negative effect has to do with the quality of Enugu Coal $[1,5]$. However, to address the problem of cost of production the $5 \%$ $15 \%$ range of blending with Enugu coal which produces a reasonable grade of tin metal is recommended; to reduce the cost of importing a ton of anthracite by $\$ 136$ [11].

\section{Conclusions}

The effect of blending Enugu coal with anthracite which is an imported coal for the smelting of tin concentrate from Dogo Na Hauwa has been investigated. The conclusions drawn from the study are as follows:

1) As the quantity of Enugu coal in the blend increases, the recovery of tin metal decreases.

2) As the quantity of Enugu coal in the blend increases, the grade/quality of the tin metal recovered decreases.

3) Considering the cost of production which is a critical issue in the survival of the smelting plants, it is recommended that smelting plants should use between $5 \%$ $15 \%$ of Enugu coal in their blends for smelting tin. This will lead to the saving of $\$ 136$ per ton of imported an- thracite used. This is a good saving when compared with the cost of anthracite per ton which is put at $\$ 906.67$.

\section{Acknowledgements}

The authors want to acknowledge the various contributions received during the course of this work. The contributions from Colleagues, Supervisors and Management of NMDC Jos; Makeri Smelting Company, Jos and Minor Metals and Minerals Dadin Kowa, Jos are all acknowledged.

\section{REFERENCES}

[1] O. O. Alabi, "Potentials of Using Blends of Anthracite/ Enugu Coal and coke/Enugu coal for Smelting of a Nigerian Cassiterite Concentrate," M.Sc. (Met.Eng) Thesis, ABU Zaria, 2010, pp. 7-14.

[2] A. P. Ihom, S. A. Abel, J Ogbodo and M. Ambayin, "The Challenges of the Metallurgical and Materials Industries in the 21st Century Nigeria: The Energy Problem," NMS Paper for Annual General Conference, 2010, pp. 1-7.

[3] O. P. Gupta, "Element of Fuels, Furnaces and Refractories," 2nd Reprint, Khanna Publishers, New Delhi, 2008, pp. 23-70.

[4] R. H. Tupkary and V. R. Tupkary, "An Introduction to Modern Iron Making," 5th Reprint, Khanna Publishers, New Delhi, 2007, pp. 48-85.

[5] G. Usman, "Research Effect at National Metallurgical Development Centre, Jos," Proceedings of the Nigerian Metallurgical Society Annual General Conference/AGM, Abuja, 1999, pp. 4-10.

[6] P. A. Wright, "Extractive Metallurgy of Tin," 2nd Edition, Elsevier Science Publishing Company, Inc., Amsterdam, 1989, pp. 93-98.

[7] L. T. Grandfield and P. G. Forester, "Properties of Tin Alloys," Tin Research Institution Publication, Greenford, 1972, p. 155.

[8] Makeri Smelting Company, "Makeri Processing Booklet and Magazine," Unpublished, 1979, pp. 1-20.

[9] O. P. Khanna, "Material Science and Metallurgy," 3rd Reprint, Dhanpat Rai Publications, New Delhi, 2008, pp. 33-1-33-7.

[10] 2009. http://enWikipedia.org/wiki/coke/fuel

[11] 2008. http://www.lme.co.uk/dataprice_daily_mineral.asp 